\title{
Does US news impact Asian emerging markets? Evidence from nonparametric causality-in-quantiles test ${ }^{*}$
}

\author{
Mehmet Balcilar ${ }^{\mathrm{a}, \mathrm{b}, \mathrm{c}}$, Esin Cakan ${ }^{\mathrm{d}}$, Rangan Gupta ${ }^{\mathrm{e}, \mathrm{f}, *}$ \\ ${ }^{a}$ Eastern Mediterranean University, Famagusta, Northern Cyprus, via Mersin 10, Turkey \\ ${ }^{\mathrm{b}}$ Montpellier Business School, Montpellier, France \\ ${ }^{\mathrm{c}}$ University of Pretoria, Pretoria 0002, South Africa \\ ${ }^{\mathrm{d}}$ Department of Economics, University of New Haven, 300 Boston Post Road, West Haven, CT 06516, USA \\ ${ }^{\mathrm{e}}$ University of Pretoria, South Africa \\ ${ }^{\mathrm{f}}$ IPAG Business School, Paris, France \\ ${ }^{*}$ Corresponding author at: Department of Economics, University of Pretoria, Pretoria, South Africa. E-mail \\ addresses: mehmet@mbalcilar.net (M. Balcilar), ecakan@ newhaven.edu (E. Cakan), rangan.gupta@up.ac.za (R. \\ Gupta).
}

\begin{abstract}
This paper aims to analyse whether US news on inflation and unemployment causes returns and volatility of seven emerging Asian stock markets from 1994 to 2014, by employing the causalityin-quantile approach. We find evidence that US news affect returns and/or volatility of all the seven stock markets considered, with these effects clustered around the tails of the conditional distribution of returns and volatility when they are either in bear or bull modes. In general, our results highlight the importance of modeling nonlinearity and studying entire conditional distributions of stock returns and volatility to draw correct inferences.
\end{abstract}

Keywords: Nonparametric quantile causality, emerging Asian markets, macroeconomic news, surprises. JEL classification: C22, C53, G1

\footnotetext{
* We would like to thank two anonymous referees for many helpful comments. However, any remaining errors are solely ours.
} 


\section{Introduction}

Emerging financial markets have been significantly influenced by changes occurring in developed economies. Globalized economic environment has led the world to experience a great financial integration in the past two decades. Given this, the purpose of our study is to examine the impact of surprises about U.S. macroeconomic news announcements on South Asian emerging financial markets. More specifically, we examine the possible causality from US macroeconomic news' shocks to stock returns and return volatility in seven emerging economies, namely India, Indonesia, Korea, the Philippines, Singapore, Taiwan, and Thailand. To capture the US inflation and unemployment news effect on emerging markets daily stock returns and volatility, we employ a recently proposed nonparametric causality-in-quantiles test by Balcilar et al. (2016, forthcoming).

Note that, the decision to choose the seven Asian economies is well-motivated based on data on portfolio investments in these economies. Foreign portfolio investors focus on stable macroeconomic environment of country. Since the impact of the Asian financial crisis on the five major equity markets of Southeast Asia in 1997-99, the global portfolio investment industry had been going through rapid change. Portfolio investors also consider the host country macroeconomic stability and exchange rate along with the interest rate. Moreover, they argue that stock market is an indicator of performance and investor expectations for host country. Portfolio flows to emerging markets reached almost \$25 billion in July 2016. Inflows were dominated by emerging markets in Asia (The Institute of International Finance, 2016). However, foreign portfolio equity in Asian countries has been volatile since 2008. The share of portfolio flows in gross capital inflows has grown since the global financial crisis. Portfolio Inflows to 
Asia between October 2008 and September 2013 has increased to almost 1\% percent of GDP (IMF staff estimates). Based on the World Development Indicators (WDI) data, the country rankings for portfolio equity net flows are as: India 12th, Indonesia 26th, Korea 17th, Singapore 175th, Phillipines 36th, Thailand $176^{\text {th }}$, with no ranking available for Taiwan, but portfolio investment have been continuously on the rise based on data available from the Bank of China. ${ }^{1}$ This ranking clearly shows how important the Asian countries are in the portfolio equity investments.

The cause of of stock market fluctuations have been studied by researchers (Chen, Roll, and Ross, 1986; Campbell and Shiller, 1988; Fama and French, 1988). Chen et al. (1986) and Fama (1981) have identified that economic news, particularly macroeconomic news, as one of the drivers of stock returns and causes of financial market fluctuations. Many studies investigate the effect of macroeconomic announcements on the volatility of the domestic financial markets. For example, Ederington and Lee (1993) find a significant effect of regularly scheduled US macroeconomic announcements on the volatility of the US treasury and foreign exchange futures. On the other hand, Cutler, Poterba, and Summers (1988) find that macroeconomic news does affect stock returns. In the case of Japan economy, Andersen, Bollerslev and Chai (2000) study the Japanese macroeconomic news announcements and find that it explains only $0.1 \%$ of variation in the intraday volatility.

Most economies are integrated with each other after the globalization took over the world, and macroeconomic announcements of major economies such as European Union, Japan and, particularly the US, are likely to not only affect their domestic financial markets, but also the financial markets of other countries (Cakan et al., 2015). Asset returns are functions of the

1 For example, refer
http://www.cbc.gov.tw/lp.asp?ctNode $=513 \& \mathrm{CtUnit}=225 \& B$ aseDSD=7\&mp $=2$.


state variables of the real economy, and the real economy itself displays significant fluctuations, with macroeconomic surprises playing a part in this (Cakan, 2012). In other words, such macroeconomic news surprises affects the US economy, and hence its stock market. At the same time, note that these seven countries are subjected to US investment flows, hence, as changes in the macroeconomic environment of the US affects its domestic and global investment potential, and thus, it is likely to feed into growth process and stock markets of these economies (Mensi et al., 2014; 2016). Moreover, US investors are interested in these emerging stock markets for risk diversification opportunities, which in turn, provide a direct channel through which a changes in the macroeconomic environment in the US, can affect stock market movements of these seven Asian emerging markets under consideration (Mensi et al., 2014; 2016). In other words, US macroeconomic news surprises are expected to affect the stock returns and volatility of these three economies, given the increased economic integration of the world economy in general, and the financial markets in particular. Note that, irrespective of whether the news are good or bad, in terms of the nature of the surprises in the US market, these emerging markets are likely to be affected, given the importance of the US economy and the extent of the global trade linkages it has with other world economies (Cakan et al., 2015). Good macroeconomic news, might imply bright future prospect for the US economy and investors would pull out investments from these emerging markets, while bad news might mean more inflow into these markets in an attempt to diversify risks. In addition, it is also possible, that investors might feel that with bad news, the US economy, and hence, the entire global economy and the world financial system is likely to slow down, so they might invest into safer assets like gold. So, whatever the type of news, both the domestic and emerging equity markets are likely to be affected based on the above channels. 
There are many examples of empirical evidence in support of the non-domestic macroeconomic news affecting the domestic financial markets. For example, Hanousek, Kocenda, and Kutan (2009), who study the reaction of asset prices to macroeconomic announcements in Hungary, Czech Republic and Poland using intraday data ${ }^{2}$ find that Czech stock market is impacted more by the U.S. macroeconomic announcements than by EU macroeconomic announcements. On the contrary, the Hungarian and the Polish stock markets are more affected by the EU macroeconomic news than US macroeconomic news. Moreover, Hanousek and Kocenda (2011) categorize EU and US macroeconomic announcements in four general classes, reducing the number from fifteen different classes previously analyzed, to study their impact on Czech, Hungarian and Polish stocks for the period from 2004 to 2007. The authors' findings suggest that the Czech, the Hungarian and the Polish stock markets have significant responses to EU macroeconomic news, but not to U.S. macroeconomic news. However, these findings have been questioned by another study on the same stock markets. Using a GARCH model and data for the period 1999-2006, Buttner, Hayo, and Neuenkirch (2012) find that both EU and US macroeconomic news significantly affect financial sectors of the above three countries. The only difference in response of the three stock markets is that the impact of EU news dominates over the impact of US news on the Czech market.

Aside from the mentioned studies above, there is limited research on the impact of economic shocks of developed economies on stock prices of emerging markets. Various other studies are concerned with the globalized outreach of other macroeconomic changes. For example, De Santis and Imrahoroglu (1997) add to the literature by studying emerging stock markets riskiness, quantified as stock market volatility, and find that except for Latin American

\footnotetext{
${ }^{2}$ The period of the data is June 2, 2003- December 29, 2006.
} 
emerging markets such as Brazil and Argentina risk is poorly reflected in stock market prices. Going beyond economic news, Onder and Mugan (2006) investigate the effect of unexpected political announcements in Turkey and Argentina. They analyze the impact of newspaper publications and find these do tend to increase the stock return volatility and trading volume on the Turkish and Argentinean stock markets. Cakan (2012) finds that there is a significantly positive relation between the long-term bond return and unemployment news during economic expansions in the US financial market. Both unemployment and inflation news surprises have impacts on volatility of the US stock market during economic recessions than during expansion. Cakan et al. (2015) analyse the impacts of US macroeconomic announcement surprises on the volatility of 12 emerging stock markets by employing asymmetric Glosten, Jagannathan, and Runkle-GARCH model with both positive and negative surprises about inflation and unemployment rate announcements in the USA. They find that volatility shocks are persistent and asymmetric volatility increases with bad news on US inflation and unemployment in at least a few cases, whilst it decreases with good news about US employment in most cases.

Recently, Lee and Chang (2011) examine the asymmetric volatility in equity returns in response to monetary policy announcements on the stock market of Taiwan. They find that the significant asymmetric effects and asymmetric volatility movements could be due to an increase in financial leverage associated with declining firm market values. Further, differencing between good and bad news, Hayo and Kutan (2005a) are among the first researchers to examine the reaction of emerging countries stock market returns and volatility as a response to IMF stabilization measures during the Asian, Russian and Brazilian crises in the period 1997-1999. Their results suggest that both good and bad news affect stock returns. More specifically, the authors find that positive IMF news tends to increase stock returns and negative IMF news tends 
to decrease stock returns by roughly one percentage point. Similar line of research is also found in Kutan and Sudjana (2003), and Evrensel and Kutan (2007, 2008a, b). Hayo and Kutan (2005b) have analyzed the impact of news oil prices, and international financial market developments, while Hayo et al., (2012a, b, 2015) have also recently looked at the role of Federal Reserve communications on equity of the US and emerging markets, and commodity market returns. In addition, the importance of domestic central banks communications for the foreign exchange market in Poland have been analyzed in Brzeszczyński and Kutan (2015). Lee et al. (2016) use monetary policy announcements of the Bank of Korea (BOK) to investigate the response of stock market liquidity by high-quality intraday transaction data from 2001-2012. Their results indicate that central bank communication, rather than FOMC announcements, plays a significant role in reducing liquidity impairment. In general, these studies indicate important roles of macroeconomis news in affecting returns and volatilities of markets considered (see for example, Brzeszczyński et al., 2015 for a detailed review in this regard).

Using a different approach, Birz and Lott (2011) study newspaper stories to show evidence that real economic news affect stock returns. Their results indicate that news about the U.S. GDP and unemployment does affect U.S. stock returns. Moreover, Birz and Dutta (2016) study the U.S. newspaper coverage provide interpretation of these releases similarly to how investors may interpret them in various economic conditions, argue that in addition to capturing the surprise component of macroeconomic releases. They find that the U.S. macroeconomic news impacts stock returns of 12 countries out of 15 advanced stock markets. Albuquerque and Vega (2009) show that it is difficult to find the effect of U.S. macro news on stock prices in large 
foreign economies, and instead, they study the effect of U.S. macroeconomic news on smaller markets such as the Portuguese stock market.

On the other hand, there are some studies on commodity markets and macroeconomic news surprises using the news-based approach of Birz and Lott (2011). For example, Caporale et al. (2016) adopts a vector autoregression-generalized autoregressive conditional heteroscedasticity approach to model the dynamic linkages between both mean and variance of macro news and commodity returns. Their findings confirm that commodities are sensitive to macroeconomic news. Some recent studies concentrate on macroeconomic news effect of the other countries rather than US.

All these studies mentioned above consider the relationship between stock returns and macroeconomic news surprises are linear. However, we need to test if their relationship is characterized by possible non-linearity, and if so, use an appropriate nonlinear methodology to study such relationships. Against this backdrop, the objective of our paper is to use the recently proposed nonparametric causality-in-quantiles test by Balcilar et al., (2016, forthcoming) to analyse whether returns and volatility of seven emerging Asian stock markets (India (SENSEX); Indonesia (SSX); South Korea (KOSPI); Philippines (PSE); Singapore (SGX); Taiwan (TAIEX); and Thailand (SET)) can be predicted by macroeconomic news related to unemployment and inflation of the U.S. economy. For this purpose we analyze daily data over the period of November 1st, 1994 to June 24th, 2014. The causality-in-quantiles test that we employ in this paper, combines the frameworks of $k$-th order causality of Nishiyama et al., (2011) and quantile causality of Jeong et al., (2012), and hence, can be considered to be a more general version of the former. The causality-in-quantile approach has the following novelties: Firstly, it is robust to misspecification errors as it detects the underlying dependence structure between the examined time series; this could prove to be particularly important, as it is well known stock returns display nonlinear dynamics in its relationship with predictors (which we show below as well), especially when we look at high frequency data (Bekiros et al., 2016b). Secondly, via this 
methodology, we are able to test for not only causality-in-mean ( $1^{\text {st }}$ moment $)$, but also causality that may exist in the tails of the joint distribution of the variables, which in turn, is particularly important if the dependent variable has fat-tails - something we show below to hold for stock returns. Finally, we are also able to investigate causality-in-variance and, thus, study higherorder dependency. Such an investigation is important because, during some periods, causality in the conditional-mean may not exist while, at the same time, higher-order interdependencies may turn out to be significant.

Note that, one could have also used nonlinear causality tests (for example, Heimstra and Jones (1994) and Diks and Panchenko $(2005,2006))$ and GARCH models to analyze the impact of US macroeconomic news surprises on returns and/or volatility of the seven Asian countries. ${ }^{3}$ However, these approaches rely on conditional-mean based estimation, and hence fail to capture the entire conditional distribution of returns and volatility - something we can do with our approach. In the process, our test is a more general procedure of detecting causality in both returns and volatility simultaneously at each point of their respective conditional distributions. Hence, we are able to capture existence or non-existence of causality at various phases (bear (lower quantiles), normal (median) and bull (upper quantiles)) of the stock markets of these countries. Being a more general test, our method is more likely to pick up causality when conditional mean-based tests might fail to do so. In addition, since we do not need decide on the number of regimes as in a Markov-switching model, and can test for causality at each point of the conditional distribution characterizing specific regimes, our test also does not suffer from any misspecification in terms of specifying and testing for the optimal number of regimes.

\footnotetext{
${ }^{3}$ In this regard, it is important to mention the work of Chiang and Doong (2001), who examine the time-series behavior of stock returns for seven Asian stock markets. They find that higher average returns appear to be associated with higher level of volatility. The authors use Threshold Autoregressive GARCH(1,1)-in-mean specification indicating that the null hypothesis of no asymmetric effect on the conditional volatility is rejected for the daily data. In other words, even if GARCH models, are used, which are in general, linear, nonlinearity needs to be incorporated in the data generating process of returns and volatility, which we do in this paper through a nonparametric approach.
} 
To the best of our knowledge, this is the first paper to employ a causality-in-quantiles approach to study the predictability of stock returns and volatility of emerging Asian markets based on US macroeconomic surprises on unemployment and inflation.

Our contributions to the existing literature are manifolds. First, we use current daily data, that spans several financial crises and captures recent reactions of emerging stock markets and analyze a large in comparison to previous studies group of countries. Our data spans from 1994 to 2014 and covers seven emerging stock markets. Second, all the studies consider the linear relationship between news surprises and the stock market. However, the relationship might be nonlinear, which we show to be the case in our dataset. We consider the possible non-linearity in the data and employ a new methodology as nonparametric quantile causality by Balcilar et al. (2016, forthcoming). This test allows us to study causality in returns and volatility over their respective conditional distributions, and hence, provide a more complete picture of the effect of surprises on the Asian emerging markets, when compared to conditional-mean based models. Third, our choice of countries is not random. We study emerging stock market countries that were recently affected by major financial crises- the Asian crisis of 1997. By focusing on these economies, we are able to understand the specific sources of stock return volatility in emerging markets and to estimate the impacts of US economic announcements in stock price index returns. Finally, note that financial market returns and its volatility (often associated with uncertainty) are among the most important indicators for practitioners, as its helps them in capital budgeting and portfolio management decisions as they directly reflect companies' financial health and future prospects (Poon and Granger, 2003; Rapach et al., 2008; Bekiros et al., 2016a). At the same time for academics, predictability of financial market movements, challenges the idea of market efficiency, and in turn, assists in building realistic asset pricing models (Rapach and Zhou, 
2013). Hence, predicting financial market returns and volatility is of paramount importance to both practitioners and academics in finance. A wide array of linear, nonlinear and nonparametric predictive models with variety of predictors related to domestic and international financial, macroeconomic, institutional, behavioural, and financial and economic uncertainty have been used (see Rapach et al., (2005); Aye et al., (2017) and Bekiros et al., (2016b) for a detailed literature reviews). In this regard, we analyze the importance of US macroeconomic news surprises in predicting movements in returns and volatility of seven major emerging Asian markets. The remainder of the paper is organized as follows: Section 2 presents the methodology, while Section 3 discusses the data and the results. Finally Section 4 concludes.

\section{Methodology}

We present here a novel methodology, as proposed by Balcilar et al., (2016, forthcoming), for the detection on nonlinear causality via a hybrid approach based on the frameworks of Nishiyama et al., (2011) and Jeong et al., (2012). We denote stock returns of the Asian economies as $\left(y_{t}\right)$ and the inflation and unemployment rate surprises used in turn as $\left(x_{t}\right)$. Following Jeong et al., (2012), the quantile-based causality is defined as follows: ${ }^{4} x_{t}$ does not cause $y_{t}$ in the $\theta$-quantile with respect to the lag-vector of $\left\{y_{t-1}, \ldots, y_{t-p}, x_{t-1}, \ldots, x_{t-p}\right\}$ if

$$
Q_{\theta}\left(y_{t} \mid y_{t-1}, \ldots, y_{t-p}, x_{t-1}, \ldots, x_{t-p}\right)=Q_{\theta}\left(y_{t} \mid y_{t-1}, \ldots, y_{t-p}\right)
$$

$x_{t}$ is a prima facie cause of $y_{t}$ in the $\theta$-th quantile with respect to $\left\{y_{t-1}, \ldots, y_{t-p}, x_{t-1}, \ldots, x_{t-p}\right\}$ if

$$
Q_{\theta}\left(y_{t} \mid y_{t-1}, \ldots, y_{t-p}, x_{t-1}, \ldots, x_{t-p}\right) \neq Q_{\theta}\left(y_{t} \mid y_{t-1}, \ldots, y_{t-p}\right)
$$

\footnotetext{
${ }^{4}$ The exposition in this section closely follows Nishiyama et al., (2011) and Jeong et al., (2012).
} 
where $Q_{\theta}\left(y_{t} \mid \cdot\right)$ is the $\theta$-th quantile of $y_{t}$ depending on $t$ and $0<\theta<1$.

Let $Y_{t-1} \equiv\left(y_{t-1}, \ldots, y_{t-p}\right), X_{t-1} \equiv\left(x_{t-1}, \ldots, x_{t-p}\right), Z_{t}=\left(X_{t}, Y_{t}\right)$, and $F_{y_{t} \mid z_{t-1}}\left(y_{t} \mid Z_{t-1}\right)$ and $F_{y_{t} \mid Y_{t-1}}\left(y_{t} \mid Y_{t-1}\right)$ denote the conditional distribution functions of $y_{t}$ given $Z_{t-1}$ and $Y_{t-1}$, respectively. The conditional distribution $F_{y_{t} \mid Z_{t-1}}\left(y_{t} \mid Z_{t-1}\right)$ is assumed to be absolutely continuous in $y_{t}$ for almost all $Z_{t-1}$. If we denote $Q_{\theta}\left(Z_{t-1}\right) \equiv Q_{\theta}\left(y_{t} \mid Z_{t-1}\right)$ and $Q_{\theta}\left(Y_{t-1}\right) \equiv$ $Q_{\theta}\left(y_{t} \mid Y_{t-1}\right)$, we have $F_{y_{t} \mid Z_{t-1}}\left\{Q_{\theta}\left(Z_{t-1}\right) \mid Z_{t-1}\right\}=\theta$ with probability one. Consequently, the hypotheses to be tested based on definitions (1) and (2) are:

$$
\begin{aligned}
& H_{0}: P\left\{F_{y_{t} \mid Z_{t-1}}\left\{Q_{\theta}\left(Y_{t-1}\right) \mid Z_{t-1}\right\}=\theta\right\}=1 \\
& H_{1}: \quad P\left\{F_{y_{t} \mid Z_{t-1}}\left\{Q_{\theta}\left(Y_{t-1}\right) \mid Z_{t-1}\right\}=\theta\right\}<1
\end{aligned}
$$

Jeong et al., (2012) employs the distance measure $J=\left\{\varepsilon_{t} E\left(\varepsilon_{t} \mid Z_{t-1}\right) f_{Z}\left(Z_{t-1}\right)\right\}$ where $\varepsilon_{t}$ is the regression error term and $f_{Z}\left(Z_{t-1}\right)$ is the marginal density function of $Z_{t-1}$. The regression error $\varepsilon_{t}$ emerges based on the null in (3), which can only be true if and only if $E\left[\mathbf{1}\left\{y_{t} \leq Q_{\theta}\left(Y_{t-1}\right) \mid Z_{t-1}\right\}\right]=\theta$ or equivalently $\mathbf{1}\left\{y_{t} \leq Q_{\theta}\left(Y_{t-1}\right)\right\}=\theta+\varepsilon_{t}$, where $\mathbf{1}\{\cdot\}$ is an indicator function. Jeong et al. (2012) specify the distance function as follows:

$$
J=E\left[\left\{F_{y_{t} \mid Z_{t-1}}\left\{Q_{\theta}\left(Y_{t-1}\right) \mid Z_{t-1}\right\}-\theta\right\}^{2} f_{Z}\left(Z_{t-1}\right)\right]
$$

In Eq. (3), it is important to note that $J \geq 0$, i.e., the equality holds if and only if $H_{0}$ in (5) is true, while $J>0$ holds under the alternative $H_{1}$ in Eq. (4). Jeong et al., (2012) show that the feasible kernel-based test statistic for $J$ has the following form:

$$
\hat{J}_{T}=\frac{1}{T(T-1) h^{2 p}} \sum_{t=p+1}^{T} \sum_{s=p+1, S \neq t}^{T} K\left(\frac{Z_{t-1}-Z_{s-1}}{h}\right) \hat{\varepsilon}_{t} \hat{\varepsilon}_{s}
$$

where $K(\cdot)$ is the kernel function with bandwidth $h, T$ is the sample size, $p$ is the lag-order, and $\hat{\varepsilon}_{t}$ is the estimate of the unknown regression error, which is estimated as follows: 


$$
\hat{\varepsilon}_{t}=\mathbf{1}\left\{y_{t} \leq \hat{Q}_{\theta}\left(Y_{t-1}\right)\right\}-\theta
$$

$\hat{Q}_{\theta}\left(Y_{t-1}\right)$ is an estimate of the $\theta$-th conditional quantile of $y_{t}$ given $Y_{t-1}$. Below, we estimate $\hat{Q}_{\theta}\left(Y_{t-1}\right)$ using the nonparametric kernel method as:

$$
\hat{Q}_{\theta}\left(Y_{t-1}\right)=\hat{F}_{y_{t} \mid Y_{t-1}}^{-1}\left(\theta \mid Y_{t-1}\right)
$$

where $\hat{F}_{y_{t} \mid Y_{t-1}}\left(y_{t} \mid Y_{t-1}\right)$ is the Nadarya-Watson kernel estimator given by:

$$
\hat{F}_{y_{t} \mid Y_{t-1}}\left(y_{t} \mid Y_{t-1}\right)=\frac{\sum_{s=p+1, s \neq t}^{T} L\left(\frac{Y_{t-1}-Y_{s-1}}{h}\right) \mathbf{1}\left(y_{s} \leq y_{t}\right)}{\sum_{s=p+1, s \neq t}^{T} L\left(\frac{Y_{t-1}-Y_{s-1}}{h}\right)}
$$

with $L(\cdot)$ denoting the kernel function and $h$ the bandwidth.

In an extension of the Jeong et al., (2012) framework, we develop a test for the 2nd moment. In particular, we want to test the causality running from the inflation and unemployment rate surprises in turn to volatility of stock returns. Causality in the $k$-th moment generally implies causality in the $m$-th moment for $k<m$. Firstly, we employ the nonparametric Granger quantile causality approach by Nishiyama et al., (2011). In order to illustrate the causality in higher order moments, consider the following process for $y_{t}$ :

$$
y_{t}=g\left(Y_{t-1}\right)+\sigma\left(X_{t-1}\right) \varepsilon_{t}
$$

where $\varepsilon_{t}$ is a white noise process; and $g(\cdot)$ and $\sigma(\cdot)$ are unknown functions that satisfy certain conditions for stationarity. However, this specification does not allow for Granger-type causality testing from $x_{t}$ to $y_{t}$, but could possibly detect the "predictive power" from $x_{t}$ to $y_{t}^{2}$ when $\sigma(\cdot)$ is a general nonlinear function. Hence, the Granger causality-in-variance definition does not require an explicit specification of squares for $X_{t-1}$. We re-formulate Eq. (10) into a null and alternative hypothesis for causality in variance as follows:

$$
H_{0}: \quad P\left\{F_{y_{t}^{2} \mid Z_{t-1}}\left\{Q_{\theta}\left(Y_{t-1}\right) \mid Z_{t-1}\right\}=\theta\right\}=1
$$




$$
H_{1}: \quad P\left\{F_{y_{t}^{2} \mid Z_{t-1}}\left\{Q_{\theta}\left(Y_{t-1}\right) \mid Z_{t-1}\right\}=\theta\right\}<1
$$

To obtain a feasible test statistic for testing the null in Eq. (10), we replace $y_{t}$ in Eq. (6) - (9) with $y_{t}^{2}$. Incorporating the Jeong et al., (2012) approach we overcome the problem that causality in the conditional 1 st moment (mean) imply causality in the 2nd moment (variance). In order to overcome this problem, we interpret the causality in higher order moments using the following model:

$$
y_{t}=g\left(X_{t-1}, Y_{t-1}\right)+\varepsilon_{t}
$$

Thus, higher order quantile causality can be specified as:

$$
\begin{aligned}
& H_{0}: \quad P\left\{F_{y_{t}^{k} \mid Z_{t-1}}\left\{Q_{\theta}\left(Y_{t-1}\right) \mid Z_{t-1}\right\}=\theta\right\}=1 \text { for } k=1,2, \ldots, K \\
& H_{1}: \quad P\left\{F_{y_{t}^{k} \mid Z_{t-1}}\left\{Q_{\theta}\left(Y_{t-1}\right) \mid Z_{t-1}\right\}=\theta\right\}<1 \text { for } k=1,2, \ldots, K
\end{aligned}
$$

Integrating the entire framework, we define that $x_{t}$ Granger causes $y_{t}$ in quantile $\theta$ up to $K$-th moment utilizing Eq. (15) to construct the test statistic of Eq. (6) for each $k$. However, it can be shown that it is not easy to combine the different statistics for each $k=1,2, \ldots, K$ into one statistic for the joint null in Eq. (14) because the statistics are mutually correlated (Nishiyama et al., 2011). To efficiently address this issue, we include a sequential-testing method as described Nishiyama et al. (2011) with some modifications. Firstly we test for the nonparametric Granger causality in the 1 st moment $(k=1)$. Rejecting the null of non-causality means that we can stop and interpret this result as a strong indication of possible Granger quantile causality-in-variance. Nevertheless, failure to reject the null for $k=1$, does not automatically leads to no-causality in the 2nd moment, thus we can still construct the tests for $k=2$. Finally, we can test the existence of causality-in-variance, or the causality-in-mean and variance successively. The empirical implementation of causality testing via quantiles entails specifying three important choices: the 
bandwidth $h$, the lag order $p$, and the kernel type for $K(\cdot)$ and $L(\cdot)$ in Eq. (6) and (9) respectively. In our study, a lag order of 1 is used. Note that, this choice of the lag-length is in line with the fact that there is a time-lag of one day between the announcements in the U.S. and its possible effect on the Asian markets, given the closing times in these markets as discussed in detail below. However, the Schwarz Information Criterion (SIC) under a VAR comprising of stock returns and the inflation and unemployment rate surprises used in turn also picked a laglength of one as optimal. The SIC being parsimonious when it comes to choosing lags compared to other alternative lag-length selection criterion, helps us to prevent issues of overparametrization commonly associated with nonparametric approaches. The bandwidth value is selected using the least squares cross-validation method. Lastly, for $K(\cdot)$ and $L(\cdot)$ we employ Gaussian-type kernels.

\section{Data and Empirical Results}

The data set used in this study includes the daily stock price indexes in domestic currency for seven emerging Asian stock markets for the period of November 1st, 1994 to June 24th, $2014 .^{5}$ More specifically we analyze the stock indexes of: India (SENSEX); Indonesia (SSX); South Korea (KOSPI); Philippines (PSE); Singapore (SGX); Taiwan (TAIEX); and Thailand (SET). The source of the data on the above listed stock price indexes is Datastream. The daily composite

\footnotetext{
${ }^{5}$ The purpose of our study is to capture some historical effects. To that goal we are using daily data spanning over 20 years. We are aware that some other studies have focused on more narrow period of time, such as 4-5 years and have used intra-day data. Unlike these studies we are not capturing the "immediate" or intra-day effect of the surprises.
} 
stock returns are defined as logarithmic difference of the daily stock index $\left(P_{t}\right)$ times 100, i.e. $R_{t}=100 *\left(\log P_{t}-\log P_{t-1}\right)$.

The macroeconomic announcements related to inflation and unemployment rate are collected respectively from the websites of the Bureau of Economic Analysis (BEA) and the Bureau of Labor Statistics (BLS). ${ }^{6}$ Inflation and unemployment rate announcements are released at 8:30 am US Eastern time. Given this and the fact that we look at Asian markets, the effects of inflation and unemployment news occur with a day lag for our seven chosen economies. ${ }^{7}$ Table 1 summarizes the opening and closing times of the local stock exchanges, their time differences with respect to U.S. EST, as well as the local market day in course when the US news is released.

\begin{tabular}{|c|c|c|c|c|}
\hline Exchange & $\begin{array}{l}\text { Opening-Closing in } \\
\text { local time }\end{array}$ & $\begin{array}{l}\text { Time difference } \\
\text { from NY }\end{array}$ & $\begin{array}{l}\text { CPI news in } \\
\text { local time }\end{array}$ & $\begin{array}{l}\text { UR news in } \\
\text { local time }\end{array}$ \\
\hline India & 9:00 am - 3:30 pm & ( +9.5 hours $)$ & +1 day & +1 day \\
\hline Indonesia & 9:00 am-6:00 pm & (+11 hours) & +1 day & +1 day \\
\hline Korea & 9:00 am-3:00 pm & (+13 hours) & +1 day & +1 day \\
\hline Philippines & 9:00am-12:10 pm & (+12 hours) & +1 day & +1 day \\
\hline Singapore & 9:00am-5:00 pm & (+8 hours) & +1 day & +1 day \\
\hline Taiwan & 9:00 am-1:30 pm & (+12 hours) & +1 day & +1 day \\
\hline Thailand & 10:00 am-12:30 pm & (+11 hours) & +1 day & +1 day \\
\hline
\end{tabular}

\footnotetext{
${ }^{6}$ Corresponding web sites are www.bea.gov; www.bls.org.

${ }^{7}$ Note that in our data set, we do retain the days for which the Asian markets were closed, but an US macroeconomic announcement was made. This make sense, since these markets are closed when US announcements are made, and we are conducting a causality analysis, which by design controls for the fact that US macroeconomic news affects the Asian markets only a day after the announcement. The number of cases for which US announcements were made and markets were closed in Asia were quite few; specifically, India: 14; Indonesia: 18; South Korea: 14; Philippines: 13; Singapore: 9; Thailand: 21, and; Taiwan: 18 out of a total of 141 and 171 inflation and unemployment news surprises respectively. When we re-conducted the analysis by dropping these dates our results were both qualitatively and quantitatively similar, given the small number of such instances. Complete details of these results are available upon request from the authors.
} 
We have a total of 5126 observations for all countries. The sample period includes 229 announcements of US macroeconomic news. We obtain market expectations for inflation and unemployment rate from the Money Market Survey from 1994 to 2005 and Bloomberg Terminal Bloomberg Survey from 2005 to 2014. Based on the market expectations, we calculate the surprise element of the US macroeconomic news announcements.

Let $F_{i}$ denote the median of the Bloomberg forecast survey and $\mathrm{A}_{\mathrm{i}}$ the released value of announcement $i$. We measure the surprise in announcements $i$ as:

$$
E_{i t}=A_{i t}-F_{t-\delta i}\left(A_{t}\right)
$$

Further, we standardize the surprises $E_{\mathrm{t}}$ by dividing them by their standard deviation across all observations to facilitate interpretation. The standardized surprise measure therefore is:

$$
S_{i}=\frac{E_{i}}{\sigma_{i}}
$$

Following Balduzzi, Elton and Green (2001), we compute the unexpected components of the announcements as the standardized differences between the actual announcement values and their median expected values.

In order to provide a general understanding of the emerging markets and compare their distinct properties, we present summary statistics of daily returns for each country in Table 2. The statistics include mean return, standard deviation, skewness, excess kurtosis, and normality. The mean daily return ranges from of $0 \%$ to $0.04 \%$, while the standard deviations range from $1.7 \%$ to $3.15 \%$. This result clearly indicates that the emerging stock markets are characterized by high volatility. The most volatile market appears to be Korea's stock market and the most stable 
one - the Indian stock market. In most cases, higher returns are associated with higher volatility and vice versa (Table 2). All the markets have excess kurtosis, and most have negative skewness (Table 2). Excess kurtosis indicates that the return distribution is not Gaussian, which is typical of financial data. This non-normality result in turn, provides a preliminary motivation to look at the effect of the U.S. news over the entire conditional distribution of stock returns (and volatility), rather than just at the conditional-mean. In Figure 1, we plot the stock market return series for each country.

Figure 1. Plots of Stock Returns of the Seven Emerging Asian Markets
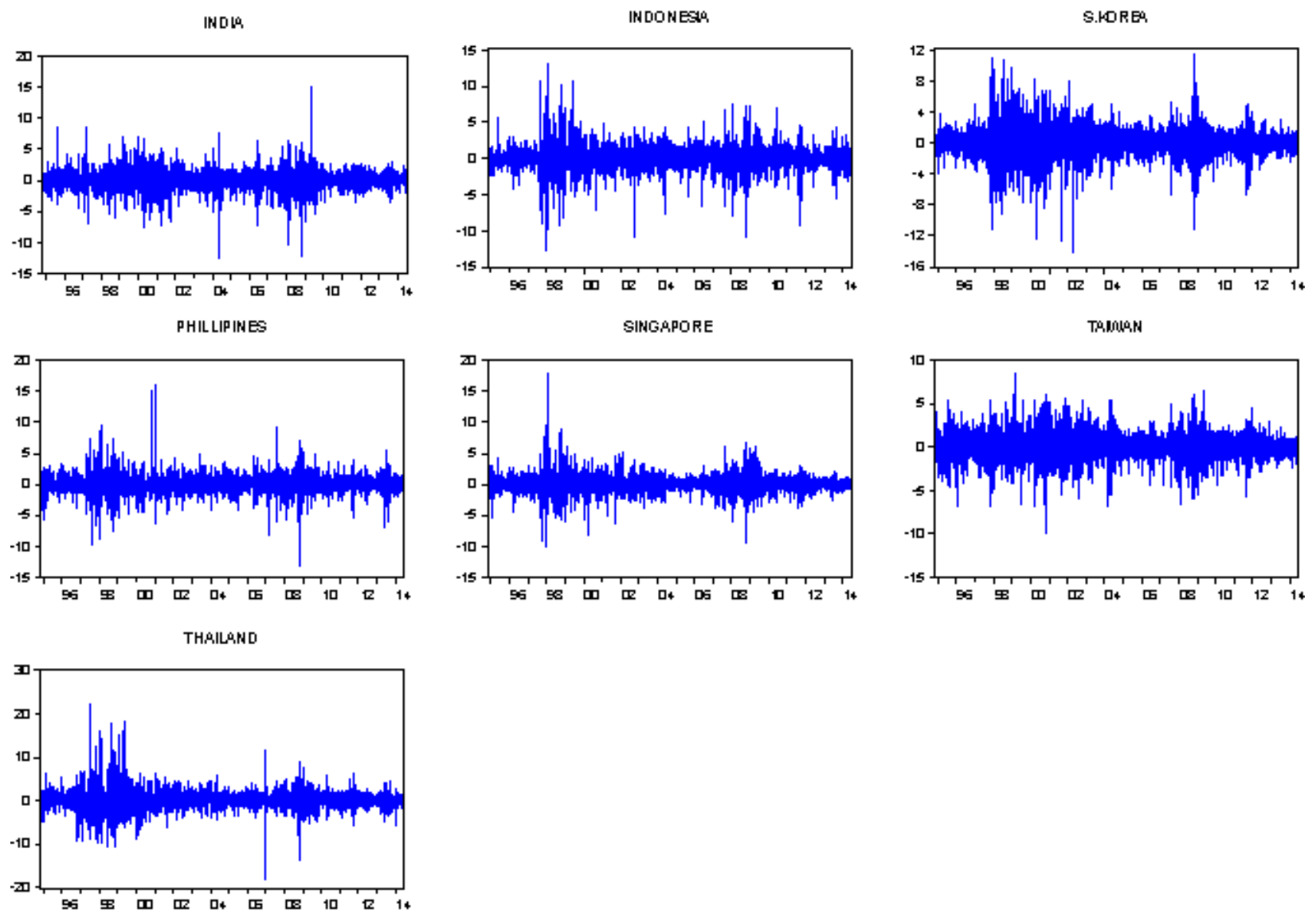


\begin{tabular}{|l|c|c|c|c|c|c|c|}
\hline Table 2. Descriptive statistics of daily stock index returns in Asian emerging markets \\
\hline Returns & Mean & St. Dev. & Min & Max & $\begin{array}{c}\text { Skew- } \\
\text { ness }\end{array}$ & Kurtosis & JB \\
\hline India & -0.00567 & 1.698 & -11.343 & 8.1647 & -0.173 & 5.661 & $1084.2(0.0)$ \\
\hline Indonesia & -0.0212 & 2.138 & -17.895 & 16.046 & 0.175 & 10.447 & $8368.2(0.0)$ \\
\hline Korea & 0.03891 & 3.153 & -27.485 & 22.135 & -0.191 & 9.200 & $5810.0(0.0)$ \\
\hline Philippines & -0.00430 & 2.847 & -37.592 & 22.542 & -0.978 & 23.995 & $66934.6(0.0)$ \\
\hline Singapore & -0.02748 & 1.756 & -13.865 & 18.830 & 0.366 & 12.867 & $14740.2(0.0)$ \\
\hline Taiwan & 0.01997 & 2.048 & -13.033 & 13.868 & -0.202 & 7.004 & $2437.75(0.0)$ \\
\hline \begin{tabular}{l} 
Thailand \\
\hline
\end{tabular} & 0.06386 & 3.067 & -27.472 & 23.729 & -0.6089 & 14.529 & $20234.5(0.0)$ \\
\hline $\begin{array}{l}\text { Notes: All numbers are in percentages. All statistics are for daily series from 31 May 1994 to 24 June 2014, yielding } \\
\text { 5126 observations. All stock index prices are expressed in domestic currency. Under the null hypothesis of a normal } \\
\text { distribution, the Jargue-Bera (JB) statistics for normality statistic measures the difference between the skewness and } \\
\text { kurtosis of the series with those from the normal distribution. } p \text {-values are provided in parentheses. }\end{array}$ \\
\hline
\end{tabular}

Though our objective is to analyse the causality-in-quantiles running from US news on unemployment and inflation to stock returns and its volatility, for the sake of completeness and comparability, we also conducted the standard linear Granger causality test based on a VAR(1) model. The results have been reported in Table 3. As can be seen, there is no evidence of causality running from the either inflation or unemployment news surprises on the stock returns of the seven Asian economies at the conventional 5 percent level of significance.

\begin{tabular}{|l|l|l|}
\hline Table 3. Linear Granger Causality Test \\
\hline Country & $\begin{array}{l}F \text {-stat: Inflation Surprise } \\
\text { does not Granger Cause } \\
\text { Stock Returns }\end{array}$ & $\begin{array}{l}\text { F-stat: Unemployment } \\
\text { Surprise does not Granger } \\
\text { Cause Stock Returns }\end{array}$ \\
\hline India & 0.35 & 2.74 \\
\hline Indonesia & 0.92 & 1.09 \\
\hline South Korea & 0.02 & 0.08 \\
\hline Philippines & 2.74 & 0.01 \\
\hline Singapore & 0.19 & 0.26 \\
\hline China & 0.06 & 1.81 \\
\hline Taiwan & 0.39 & 0.02 \\
\hline
\end{tabular}


Next, to motivate the use of the nonparametric quantile-in-causality approach, we statistically investigate the possibility of nonlinearity in the relationship between the stock returns and the US unemployment and inflation news surprises. To this end, we apply the Brock et al., (1996, BDS) test on the residuals of the stock returns equation in the VAR(1) model, as reported in Table 3. The results provide ample evidence of the rejection of the null of i.i.d. residuals at various embedded dimensions $(m)$, for all cases considered. These results provide strong evidence of nonlinearity in the relationship between stock returns and inflation and unemployment news of the US. ${ }^{8}$ Hence,, the results based on the linear Granger causality test, cannot be deemed robust and reliable.

Table 4. Brock et al., (1996, BDS) Test

\begin{tabular}{|c|c|c|c|c|c|}
\hline 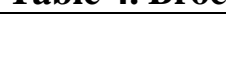 & & $P a r$ & BDS Test $\mathrm{i}$ & lation $\mathrm{Ne}$ & \\
\hline & & & $m$ & & \\
\hline Country & 2 & 3 & 4 & 5 & 6 \\
\hline India & $17.43 *$ & $21.30 *$ & $24.27 *$ & $26.96^{*}$ & $29.68^{*}$ \\
\hline Indonesia & $20.18^{*}$ & $24.39^{*}$ & $27.25^{*}$ & $29.59 *$ & $31.48^{*}$ \\
\hline South Korea & $12.63 *$ & $18.73^{*}$ & $23.15^{*}$ & $27.17 *$ & $31.40^{*}$ \\
\hline Philippines & $15.68^{*}$ & 19.54* & $22.26^{*}$ & $24.48^{*}$ & $26.61 *$ \\
\hline Singapore & $17.47 *$ & $24.35^{*}$ & $28.95^{*}$ & $32.81^{*}$ & $36.74 *$ \\
\hline China & $19.68 *$ & $24.83^{*}$ & $28.82 *$ & $31.73^{*}$ & $34.70 *$ \\
\hline Taiwan & $8.71^{*}$ & $14.51^{*}$ & $18.49^{*}$ & $21.88^{*}$ & $25.03^{*}$ \\
\hline & & Panel & Test with & ployment & \\
\hline & & & $m$ & & \\
\hline Country & 2 & 3 & 4 & 5 & 6 \\
\hline India & $17.45^{*}$ & $21.33^{*}$ & $24.29 *$ & $26.99 *$ & $29.73^{*}$ \\
\hline Indonesia & $20.15^{*}$ & $24.38 *$ & $27.27 *$ & $29.61 *$ & $31.50^{*}$ \\
\hline South Korea & $12.64 *$ & $18.73^{*}$ & $23.15^{*}$ & $27.18 *$ & $31.41 *$ \\
\hline Philippines & $15.66^{*}$ & $19.56^{*}$ & $22.31 *$ & $24.51^{*}$ & $26.65^{*}$ \\
\hline Singapore & $17.47 *$ & $24.35^{*}$ & $28.96^{*}$ & $32.82 *$ & $36.75^{*}$ \\
\hline China & $19.69 *$ & $24.87 *$ & $28.87 *$ & $31.78 *$ & $34.77 *$ \\
\hline Taiwan & $8.73^{*}$ & $14.52 *$ & $18.50 *$ & $21.89^{*}$ & $25.04 *$ \\
\hline
\end{tabular}

\footnotetext{
${ }^{8}$ When we applied the BDS test to the residuals of the AR(1) model for stock returns, we obtained similar results, i.e., stock returns were found to be strongly nonlinear as the null of i.i.d residuals was rejected at the highest level of significance for all dimensions considered. This suggested that the nonlinear specification of the null-hypothesis of no Granger causality in equation (10) is a valid one. Complete details of these results are available upon request from the authors.
} 
Next, we turn to the Bai and Perron (2003) test of multiple structural breaks, applied again to the and the stock returns equation in the VAR(1) model involving the US news on unemployment and inflation in turn. These results have been reported in Table 4. As can be seen barring the case of India in its relationship with the unemployment news, and that of Taiwan under both unemployment and inflation news, there is one break in all the other cases. ${ }^{9}$ These break dates are primarily during the East Asian crisis, with India showing the break during the global financial crisis. So, as under the BDS test which detected nonlinearity, existence of structural breaks in the relationship between Asian stock returns with the US macroeconomic news variables, imply that the Granger causality tests based on a linear framework is likely to suffer from misspecification. Given the strong evidence of either nonlinearity or regime changes or both in all the relationships between stock returns and the US news on unemployment and inflation used separately, we now turn our attention to the causality-in-quantiles test.

Table 5. Bai and Perron (2003) Test of Multiple Structural Breaks

\begin{tabular}{|c|c|c|}
\hline Country & Break Date with Inflation News & $\begin{array}{c}\text { Break Date with } \\
\text { Unemployment News }\end{array}$ \\
\hline India & $1 / 23 / 08$ & --- \\
\hline Indonesia & $1 / 15 / 98$ & $1 / 15 / 98$ \\
\hline Korea & $4 / 18 / 00$ & $10 / 29 / 97$ \\
\hline Philippines & $9 / 18 / 98$ & $9 / 18 / 98$ \\
\hline Singapore & $1 / 13 / 98$ & $1 / 13 / 98$ \\
\hline Thailand & $9 / 3 / 98$ & $9 / 3 / 98$ \\
\hline Taiwan & --- & --- \\
\hline
\end{tabular}

In Figures 2 and 3, we present the results obtained from the quantile causality test for the seven Asian emerging stock market returns and volatility originating from inflation and unemployment

\footnotetext{
${ }^{9}$ The Bai and Perron (2003) tests applied to the AR(1) model of stock returns detected one break each for all the seven economies. The dates were as follows: India: 1/29/1998; Indonesia: 1/15/1998; South Korea: 10/29/1997; Philippines: 9/18/1998; Singapore: 1/13/1998; Taiwan: 10/16/2008, and Thailand: 9/03/1998. So barring Taiwan, all the break dates are concentrated during the East Asian crisis.
} 
news, respectively. We first focus on the case of the inflation news of the US on the stock returns. As can be seen from Figure 2, barring the case of Philippines, there is evidence of causality for the other six countries at certain parts of the conditional distribution. In particular, the rejection of the null of no-causality is concentrated more around the lower and upper quantiles, barring the case of Taiwan, where causality only holds at the median, and for India, the median is also included, besides the other parts of the distribution. When we look at volatility, the evidence is relatively weak with causality showing up only for Korea, and now Philippines. For Korea, US news on inflation is found to cause volatility at higher quantiles, while the opposite is true for Philippines, where causality holds at the lower end of the conditional distribution.

Next we turn to the case of US news on unemployment, as reported in Figure 3 . The results are qualitatively similar to those reported in Figure 2 for the inflation news. Again, there is no causality for Philippines when we look at stock returns, ${ }^{10}$ and causality exists for Korea and Philippines only, when we consider volatility. ${ }^{11}$

In sum, evidence that US news on inflation and unemployment causes stock returns in seven Asian economies is non-existent in the linear model. However, as we show, the standard Granger causality results cannot be relied upon due to the existence of nonlinearity and structural

\footnotetext{
10 There are minor differences for Korea and Thailand for the case of stock returns under inflation and unemployment news cases. For Korea, the statistic is significant at quantile 0.85 under inflation news, while it is not the case under unemployment news. And for Thailand, the statistic is significant at quantile 0.30 and 0.85 under unemployment news, but not under inflation news.

${ }^{11}$ Based on the suggestion of an anonymous referee, who was concerned with the sudden spike around the median for the case of Taiwanese returns, we conducted two robustness checks: (a) We sourced data from Bloomberg instead of Datastream and reconducted the analysis to obtain quantitatively and qualitatively similar results, and; (b) Based on data availability, we also looked at the impact of Japanese macroeconomic surprises on the stock returns and volatility of Taiwan. Again, in this case, a similar picture emerged with causality in returns only being concentrated around the median over the quantile range of 0.45 to 0.65 . Note, the Japanase macroeconomic news surprise data starts in $15^{\text {th }}$ May, 2003, and was obtained from Scotti (2016), available for download at: https://sites.google.com/site/chiarascottifrb/research/surprise-and-uncertainty-indexes. Complete details of these results are available upon request from the authors.
} 
breaks. Given this, when we look into the nonparametric causality-in-quantiles test, which is robust to misspecifications, we find evidence of news on US inflation and unemployment affecting returns and/or volatility in all of the seven stock markets considered. In addition, the effect is primarily around the tails of the conditional distributions of returns and volatility, suggesting that US news tends to affect the Asian markets when they are either bearish or bullish, but not necessarily when they are operating in the average mode.

Figure 2. Causality-in-Quantiles due to US Inflation News Surprises
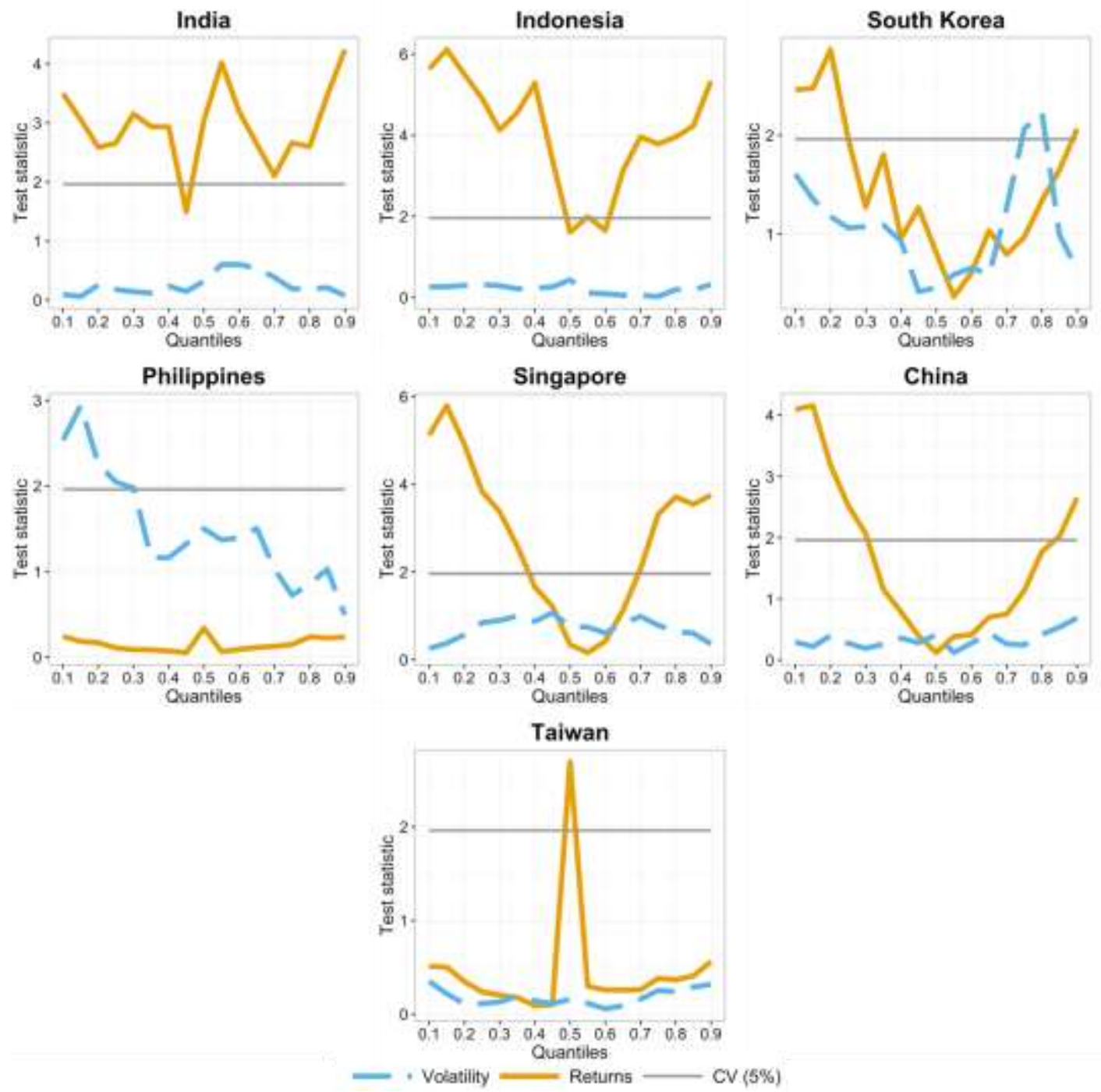
Figure 3. Causality-in-Quantiles due to US Unemployment News Surprises
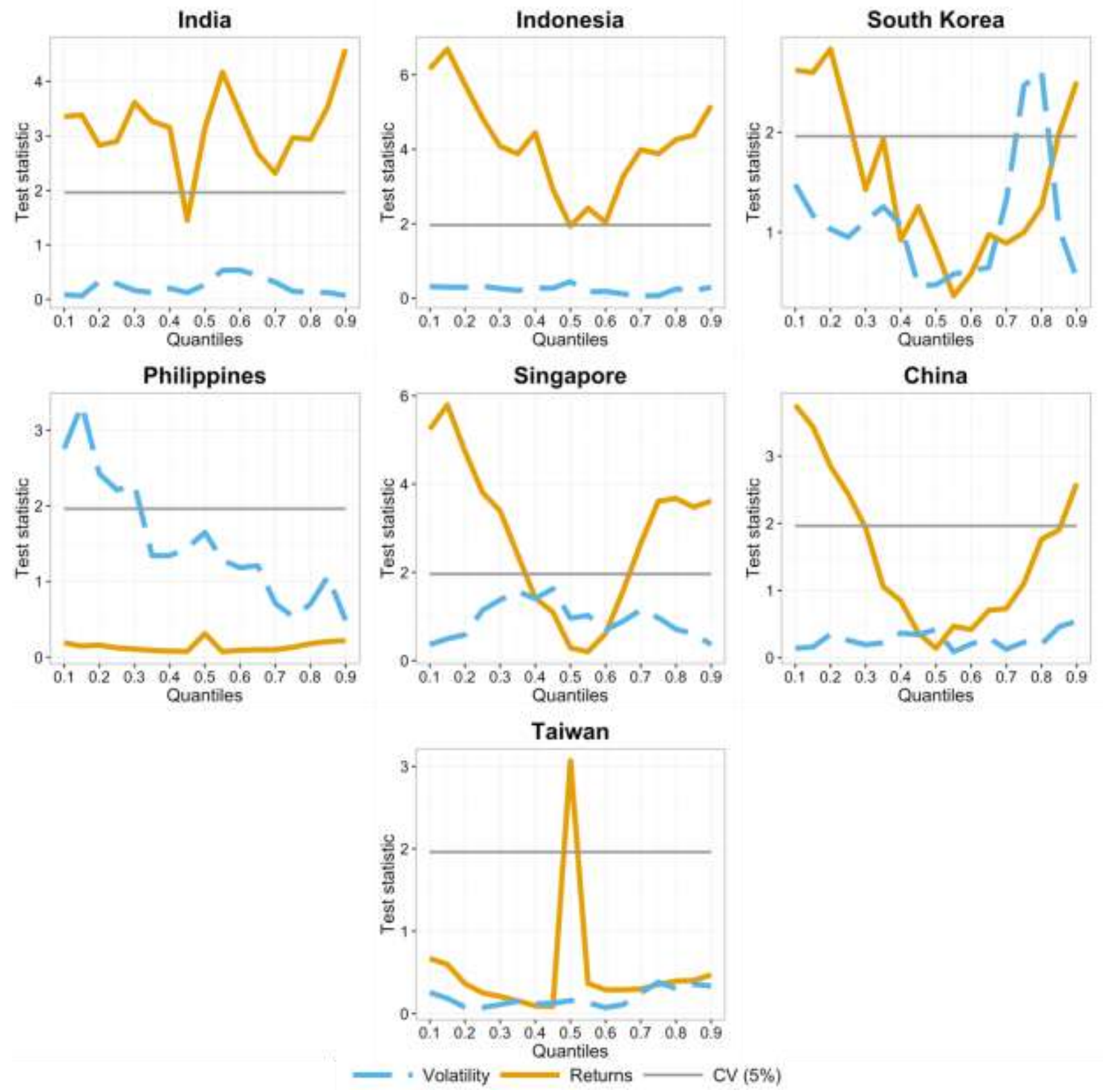

\section{Summary and Conclusion}

The objective of our paper is to use the recently proposed $k$-th order nonparametric causality-inquantiles test by Balcilar et al., (2016, forthcoming) to analyse whether US news on inflation and 
unemployment news surprises cause returns and volatility of seven emerging Asian stock markets (India, Indonesia, South Korea, Philippines, Singapore, Taiwan and Thailand). Based on daily data over the period of November 1st, 1994 to June 24th, 2014, we can draw the following conclusions: (i) Linear Granger causality test fail to find any evidence of stock returns predictability emanating from US news on inflation and unemployment; (ii) However, tests of nonlinearity and regime changes find overwhelming evidence of the linear framework being misspecified; (iii) So relying on the robust $k$-th order nonparametric causality-in-quantiles test, we find that there is evidence that US news affects either returns and/or volatility in all of the seven stock markets, and; (iv) The results from the causality-in-quantiles test tend to suggest that the effects of US news cluster around the tails of the conditional distribution of returns and volatility, implying that inflation and unemployment surprises in the US affects the Asian stock markets when they are either in bear or bull modes. Statistically, the results make sense, given the heavy-tails of the distribution, especially towards the lower-end of the market. This result is intuitive in the sense that when markets are performing normally, market agents possibly herd and do not require outside information to predict the future returns and risk (volatility); however, when the markets are not doing well or performing exceptionally well, the investors look for other information to improve or enhance returns on their portfolios.

In general, our results highlight the importance of accounting for nonlinearity when dealing with financial markets, since inference based on linear models is likely to be erroneous. In this regard, what is also important is analyzing entire conditional distributions of both returns and volatility. As part of future research, it would be interesting to extend our analysis to a forecasting exercise, 
since in-sample predictability does not necessarily guarantee the same over the out-of-sample (Rapach and Zhou, 2013). ${ }^{12}$

Finally, from the perspectives of investors and policy makers our results have important implications. First, let us consider the policy makers: If the policy makers in these economies do change their policy decisions in response to financial conditions, of which stock market is an important component, then they need to be aware that US macroeconomic news surprises do affect their domestic equity markets. But this effect is time-varying, with it being contingent on the current state of the market, as captured by a nonlinear framework. In this regard, our results also implies that they would conclude incorrectly of a no-effect of US macroeconomic news surprises on their domestic financial markets if they had used a linear framework. In other words, they need to monitor the effect of US macroeconomic news surprises on their domestic financial markets on a regular basis, as the effect is time-varying and depends on whether the equity markets are in bear, normal or bull modes. As far as international investors are concerned, if they would have relied on a linear framework, just like the policy makers, they would have concluded incorrectly that these seven Asian markets are unaffected by US macroeconomic news surprises and hence, always have diversification benefits. But this is only partially true, as shown by our causality-in-quantiles results. More specifically, diversification benefits are only available when

\footnotetext{
${ }^{12}$ At this stage, the nonparametric causality-in-quantiles test remains only a test of in-sample predictability and has not been extended to accommodate for out-of-sample forecasting. Given this, we leave this for future research. However, based on the suggestions of an anonymous referee, we used standard quantile regressions to forecast stock returns and volatility of the seven Asian economies based on the two macroeconomic news surprises of the US. Our results indicated that for all the countries and both the surprises, there is at least one quantile for which the model with surprises outperformed the model without it. Complete details of these results are available upon request from the authors. Note for our purpose, as is a quite standard practice (see for example Rapach et al., 2005), we spli the total sample into half for the in- and out-of-samples. It is important to point out that, since we have nonlinearity and structural breaks in the relationships, ideally we would need to use the nonparametric causality-in-quantiles model for forecasting rather than a linear quantile model to avoide misspecification. Hence, our forecasting results from the linear quantile model should be viewed with caution, but it does provide evidence of the information content of the two US macroeconomic news surprises in forecasting stock returns and volatility of the seven Asian economies under consideration.
} 
these markets are in normal mode, with the exception of Taiwan, where investment is likely to be unaffected in its bear and bull regimes. For domestic investors, information on US macroeconomic surprises can be used to earn profits depending on the state of the market. Finally for academicians, our results indicate that the efficient market hypothesis in these markets does not hold relative to US macroeconomic news surprises, when using nonparametric quantile-based models. when analyzing Overall, our results direct the policy makers and investors (domestic and international) to rely on a state-contingent nonparametric framework capturing the relationship between US macroeconomic news and domestic equity markets, rather than a linear model, before making their policy and investment decisions respectively. For academic purposes, these models can be used to predict movements in returns and volatility of the equity markets of these seven emerging Asian countries.

\section{References}

Albuquerque, R., \& Vega, C. (2009). Economic news and international stock market comovement. Review of Finance, 13(3), 401-465.

Amin, K. I., \& Ng, V. K. (1993). Option valuation with systematic stochastic volatility. The Journal of Finance, 48(3), 881-910.

Andersen, T. G., Bollerslev, T., \& Cai, J. (2000). Intraday and interday volatility in the Japanese stock market. Journal of International Financial Markets, Institutions and Money, 10(2), 107130.

Aye, G. C., Balcilar, M., and Gupta, R. (2017). International stock return predictability: Is the role of US time-varying? Empirica, 44(1), 121-146.

Bai, J. and Perron, P. 2003. Computation and analysis of multiple structural change models. Journal of Applied Econometrics 18, 1-22. 
Balcilar, M., Bekiros, S., and Gupta, R. (Forthcoming). The role of news-based uncertainty indices in predicting oil markets: a hybrid nonparametric quantile causality method. Empirical Economics.

Balcilar, M., Gupta, R., Kyei, C., and Wohar, M.E. (2016). Does Economic Policy Uncertainty Predict Exchange Rate Returns and Volatility? Evidence from a Nonparametric Causality-inQuantiles Test. Open Economies Review 27(2), 229-250.

Basdas, U., \& Oran, A. (2014). Event studies in Turkey. Borsa Istanbul Review, 14(3), 167-188.

Balduzzi, P., Elton, E. J., \& Green, T. C. (2001). Economic news and bond prices: Evidence from the US Treasury market. Journal of Financial and Quantitative Analysis, 36(04), 523-543.

Bekaert, G., \& Harvey, C. R. (1997). Emerging equity market volatility. Journal of Financial economics, 43(1), 29-77.

Bekaert, G., \& Wu, G. (2000). Asymmetric volatility and risk in equity markets. Review of Financial Studies, 13(1), 1-42.

Bekiros, S., Gupta, R., and Kyei, C. (2016a). On economic uncertainty, stock market predictability and nonlinear spillover effects. North American Journal of Economics and Finance, 36, 184-191.

Bekiros, S., Gupta, R., and Majumdar, A., (2016b). Incorporating Economic Policy Uncertainty in US Equity Premium Models: A Nonlinear Predictability Analysis. Finance Research Letters, 18, 291-296.

Birz, G., \& Lott, J. R. (2011). The effect of macroeconomic news on stock returns: New evidence from newspaper coverage. Journal of Banking \& Finance, 35(11), 2791-2800.

Birz, G., \& Dutta, S. (2016). US Macroeconomic News and International Stock Prices: Evidence from Newspaper Coverage. Accounting and Finance Research, 5(1), p247.

Bollerslev, T. (1986). Generalized autoregressive conditional heteroskedasticity. Journal of econometrics, 31(3), 307-327.

Brock, W., Dechert, D., Scheinkman, J., LeBaron, B., 1996. A test for independence based on the correlation dimension. Econometric Reviews, 15 197-235.

Brzeszczyński, J., Gajdka, J., \& Kutan, A.M. (2015). Investor response to public news, sentiment and institutional trading in emerging markets: A review. International Review of Economics \& Finance, 40(C), 338-352. 
Brzeszczyński, J., \& Kutan, A.M. (2015). Public information arrival and investor reaction during a period of institutional change: An episode of early years of a newly independent central bank. Journal of Comparative Economics, 43(3), 727-753.

Buttner, D., Hayo, B., \& Neuenkirch, M. (2012). The impact of foreign macroeconomic news on financial markets in the Czech Republic, Hungary, and Poland. Empirica, 39(1), 19-44.

Cakan, E. (2012). The Business Cycle And Impacts Of Economic News On Financial Markets. Journal of Business \& Economics Research. 10(6), 385-390.

Cakan. E., Doytch, N., \& Upadhyaya, K.P. (2015). Does U.S. macroeconomic news make emerging financial markets riskier. Borsa Istanbul Review, 15(1), 37-43.

Campbell, J. Y., \& Hentschel, L. (1992). No news is good news: An asymmetric model of changing volatility in stock returns. Journal of Financial Economics, 31(3), 281-318.

Campbell, J. Y., \& Shiller, R. J. (1988). The dividend-price ratio and expectations of future dividends and discount factors. Review of Financial Studies, 1(3), 195-228.

Caporale, G. M., Spagnolo, F., \& Spagnolo, N. (2017). Macro news and commodity returns. International Journal of Finance \& Economics, 22, 68-80.

Chen, NF., Roll, R. \& Ross, S. (1986). Economic forces and the stock market. The Journal of Business, 59, 383-403.

Chiang, T. C., \& Doong, S. C. (2001). Empirical analysis of stock returns and volatility: Evidence from seven Asian stock markets based on TAR-GARCH model. Review of Quantitative Finance and Accounting, 17(3), 301-318.

Cutler, D. M., J. M. Poterba and Summers, L. H. (1988). What Moves Stock Prices?. NBER Working Paper no. 2538, National Bureau of Economic Research, Cambridge, MA.

De Santis, G. \& Imrohoroglu, S. (1997). Stock returns and volatility in emerging financial markets. Journal of International Money and Finance, 16(4), 561-579.

Diks, C. G. H., and Panchenko, V. (2005). A note on the Hiemstra-Jones test for Granger noncausality. Studies in Nonlinear Dynamics and Econometrics, 9(2), 1-7.

Diks, C. G. H., and Panchenko, V. (2006). A new statistic and practical guidelines for nonparametric Granger causality testing. Journal of Economic Dynamics and Control, 30(9-10), 1647-1669.

Duan, J. C. (1995). The GARCH option pricing model. Mathematical finance, 5(1), 13-32.

Ederington, L. H., \& Lee, J. H. (1993). How markets process information: News releases and volatility. The Journal of Finance, 48(4), 1161-1191. 
Engle, R. F., \& Ng, V. K. (1993). Measuring and testing the impact of news on volatility. The journal of finance, 48(5), 1749-1778.

Evrensel, A. \& Kutan, A.M. (2007). IMF-related announcements and stock market returns: Evidence from financial and non-financial sectors in Indonesia, Korea, and Thailand. PacificBasin Finance Journal, 15(1), 80-104.

Evrensel, A. \& Kutan, A.M. (2008a). How do IMF announcements affect financial markets in crises?: Evidence from forward exchange markets. Journal of Financial Stability, 4(2), 121-134.

Evrensel, A. \& Kutan, A.M. (2008b). Impact of IMF-related news on capital markets: Further evidence from bond spreads in Indonesia and Korea. Journal of International Financial Markets, Institutions and Money, 18(2), 147-160.

Fama, E. F. (1981). Stock returns, real activity, inflation, and money. The American Economic Review, 545-565.

Fama, E. F., \& French, K. R. (1988). Permanent and temporary components of stock prices. The Journal of Political Economy, 246-273.

Glosten, L. R., Jagannathan, R., \& Runkle, D. E. (1993). On the relation between the expected value and the volatility of the nominal excess return on stocks. The Journal of Finance, 48(5), 1779-1801.

Hanousek, J., \& Kocenda, E. (2011). Foreign news and spillovers in emerging European stock markets. Review of International Economics, 19(1), 170-188.

Hanousek, J., Kocenda, E., \& Kutan, A. M. (2009). The reaction of asset prices to macroeconomic announcements in new EU markets: Evidence from intraday data. Journal of Financial Stability, 5(2), 199-219.

Hayo, B., \& Kutan, A. M. (2005a). IMF-related news and emerging financial markets. Journal of International Money and Finance, 24(7), 1126-1142.

Hayo, B., \& Kutan, A.M. (2005b). The impact of news, oil prices, and global market developments on Russian financial markets. The Economics of Transition, 13(2), 373-393.

Hayo, B., Kutan, A. M., \& Neuenkirch, M. (2010). The impact of US central bank communication on European and pacific equity markets. Economics Letters, 108(2), 172-174.

Hayo, B., Kutan, A.M, and Neuenkirch, M. (2012a). Federal Reserve Communications and Emerging Equity Markets. Southern Economic Journal, 78(3), 1041-1056. 
Hayo, B., Kutan, A.M, and Neuenkirch, M. (2012b). Communication matters: US monetary policy and commodity price volatility. Economics Letters, 117(1), 247-249.

Hayo, B., Kutan, A.M, and Neuenkirch, M. (2015). Financial market reaction to Federal Reserve communications: Does the global financial crisis make a difference? Empirica, 42(1), 185-203.

Hiemstra, C. and Jones, J. D. (1994). Testing for linear and nonlinear Granger causality in the stock price-volume relation. Journal of Finance, 49(5), 1639-1664.

Jeong, K., Härdle, W. K., and Song, S. (2012). A consistent nonparametric test for causality in quantile. Econometric Theory, 28(04), 861-887.

Kutan, A.M., \& Sudjana, B. (2003). Investor reaction to IMF actions in the indonesian financial crisis. Journal of Economic Policy Reform, 6(3), 181-190.

Lee, C. W., \& Chang, M. J. (2011). Announcement effects and asymmetric volatility in industry stock returns: evidence from Taiwan. Emerging Markets Finance and Trade, 47(2), 48-61.

Lee, J., Ryu, D., \& Kutan, A. M. (2016). Monetary policy announcements, communication, and stock market liquidity. Australian Economic Papers, 55(3), 227-250.

Mensi, W., Hammoudeh, S., Reboredo, J. C., Nguyen, D. K., 2014. Do global factors impact BRICS stock markets? A quantile regression approach. Emerging Markets Review 19, 1-17.

Mensi, W., Hammoudeh, S., Yoon, S-M, and Nguyen, D. K. (2016). Asymmetric Linkages between BRICS Stock Returns and Country Risk Ratings: Evidence from Dynamic Panel Threshold Models. Review of International Economics, 24(1), 1-19.

Nishiyama, Y., Hitomi, K., Kawasaki, Y., and Jeong, K. (2011). A consistent nonparametric test for nonlinear causality - Specification in time series regression. Journal of Econometrics 165, $112-127$.

Onder, Z., \& Şimga-Mugan, C. (2006). How do political and economic news affect emerging markets? Evidence from Argentina and Turkey. Emerging Markets Finance and Trade, 42(4), 50-77.

Poon, S-H, and Granger, C. W. J. (2003). Forecasting Volatility in Financial Markets: A Review. Journal of Economic Literature, 41(2), 478-539.

Rapach, D. E., Wohar, M. E., and Rangvid, J. (2005). Macro Variables and International Stock Return Predictability. International Journal of Forecasting, 21(1), 137-166.

Rapach, D. E., Wohar, M. E., and Strauss, J. (2008). Forecasting Stock Return Volatility in the Presence of Structural Breaks, in Forecasting in the Presence of Structural Breaks and Model 
Uncertainty, David E. Rapach and Mark E. Wohar (Eds.), Vol. 3 of Frontiers of Economics and Globalization, Bingley, United Kingdom: Emerald, 381-416.

Rapach, D. E., and Zhou, G. (2013). Forecasting stock returns. Handbook of Economic Forecasting, 2(Part A), Graham Elliott and Allan Timmermann (Eds.), Amsterdam: Elsevier, 328-383.

Scotti, C. (2016). Surprise and Uncertainty Indexes: Real-Time Aggregation of Real-Activity Macro Surprises. Journal of Monetary Economics, 82, 1-19.

Tsay, R. S. (1998). Testing and modeling multivariate threshold models. Journal of the American Statistical Association, 93(443), 1188-1202.

Wu, G., \& Xiao, Z. (2002). A generalized partially linear model of asymmetric volatility. Journal of Empirical Finance, 9(3), 287-319. 